\title{
Analysis of the chemical composition, antifungal activity and larvicidal action against Aedes aegypti larvae of the Essential Oil Cymbopogon nardus
}

\author{
Análise da composição química, atividade antifúngica e ação larvicida contra larvas do Aedes \\ aegypti do Óleo Essencial Cymbopogon nardus \\ Análisis de la composición química, actividad antifúngica y acción larvicida frente a larvas de
}

Aedes aegypti del Aceite Esencial Cymbopogon nardus

Received: 10/05/2021 | Reviewed: 10/13/2021 | Accept: 10/19/2021| Published: 10/21/2021

Larisse Carneiro da Frota Brito

ORCID: https://orcid.org/0000-0003-2935-4163 Universidade Federal do Piaú, Brasil E-mail: larissa_frota13@hotmail.com

Lucas Mendes Feitosa Dias

ORCID: https://orcid.org/0000-0002-8706-9945 Universidade Federal do Piaú, Brasil

E-mail: lucas.mendes1610@hotmail.com

Gilciara Sousa Santos Pereira

ORCID: https://orcid.org/0000-0001-7125-185X Universidade Federal do Piauí, Brasil

E-mail: gigscobain@gmail.com

Nayra Barbosa Alves

ORCID: https://orcid.org/0000-0001-7124-5521 Universidade Federal do Piaú, Brasil

E-mail: nayra.barbosa-17@hotmail.com

Márcio dos Santos Rocha

ORCID: https://orcid.org/0000-0001-6606-8268 Universidade Federal do Piaú, Brasil

E-mail: farmrocha@gmail.com

João Farias de Sousa Junior

ORCID: https://orcid.org/0000-0002-6559-3463 Universidade Federal do Piauí, Brasi E-mail: j.f.s.j@hotmail.com

Veruska Cavalcanti Barros

ORCID: https://orcid.org/0000-0001-8483-4528 Universidade Federal do Piauí, Brasil E-mail: vcbbio@hotmail.com

Maria Christina Sanches Muratori

ORCID: https://orcid.org/0000-0002-4569-0995 Universidade Federal do Piauí, Brasil E-mail: christina@ufpi.edu.br

\begin{abstract}
The Cymbopogon nardus L. is a plant popularly known as "citronella grass", originating from Ceylon and India, used in Indonesia as a soothing and digestive tea. The essential oil of the species Cymbopogon nardus (OECN) is used in the manufacture of cosmetics and perfumes, besides having shown antimicrobial action against Escherichia coli, Salmonella spp., Pseudomonas spp., Streptococcus spp., and in addition antioxidant, anti-inflammatory. The objective of this study was to determine the larvicidal and fungicide potential of OECN extracted from the fresh leaves of $C$. nardus. L at the beginning of the dry season in Teresina, PI. From the OECN extracted by hydrodistillation, the actives were identified by mass gas chromatography. The larvicidal action of OECN was tested against the third and fourth larval stages of Aedes aegypti at concentrations (2.5, 5.0, 7.5 and $10 \mu \mathrm{L} / 20 \mathrm{ml})$ for 24 to 48 hours. Antifungal activity for Aspergillus flavus and A. parasiticus at concentrations (1.0, 2.0, 4.06 .0 and $8.0 \mu \mathrm{L} / 10 \mathrm{~mL})$. The OECN showed a good yield (1.0\%), with 26 assets $(93.2 \%)$ identified with the majority: citronelal $(31.6 \%)$, geraniol $(22.1 \%)$, elemol $(11.8 \%)$ and citronellol (8.2\%). Mortality of $100 \%$ of the larvae was observed at concentrations of 7.5 and $10.0 \mu 1 / 20$ $\mathrm{ml}$ in 24 hours. After 48 hours $93.3 \%$ in $5.0 \mu \mathrm{l} / 10 \mathrm{ml} \mathrm{OECN}$ and $70 \%$ in $2.5 \mu \mathrm{l} / 10 \mathrm{ml}$. A flavus showed greater sensitivity to $\mathrm{OECN}$ at $8.0 \mu \mathrm{l} / 10 \mathrm{ml}$ than A. parasiticus at concentrations. A. parasiticus was the most sensitive at concentrations of 1.0 and $2.0 \mu \mathrm{L} / 10 \mathrm{~mL}$. OECN has a larvicidal action and antifungal activity at the tested concentrations.
\end{abstract}

Keywords: Essential oil; Citronella; Antifungal; Larvicidal action. 


\begin{abstract}
Resumo
O Cymbopogon nardus L. é uma planta popularmente conhecida por "capim citronela", originada do Ceilão e da Índia, utilizada na Indonésia como chá calmante e digestivo. O óleo essencial da espécie Cymbopogon nardus (OECN) é utilizado na fabricação de cosméticos e perfumes, além de ter mostrado ação antimicrobiana contra Escherichia coli, Salmonella spp., Pseudomonas spp., Streptococcus spp. e, além disso, apresenta atividade antioxidante e antiinflamatória. Objetivou-se determinar o potencial larvicida e fungicida OECN extraído das folhas frescas da $C$. nardus. L no início da estação seca em Teresina, PI. A partir do OECN extraído por hidrodistillação, os ativos foram identificados por cromatografia gasosa em massas. A ação larvicida da OECN foi testada contra o terceiro e quarto estádios larvais do Aedes aegypti nas concentrações $(2,5 ; 5,0 ; 7,5$ e $10 \mu \mathrm{L} / 20 \mathrm{ml})$ por 24 a 48 horas. A atividade antifúngica para Aspergillus flavus e A. parasiticus nas concentrações (1,0;2,0; 4,0 6,0 e 8,0 $\mu \mathrm{L} / 10 \mathrm{~mL})$. O OECN apresentou bom rendimento $(1,0 \%)$ sendo identificados 26 ativos $(93,2 \%)$ com os majoritários: citronelal $(31,6 \%)$, geraniol $(22,1 \%)$, elemol $(11,8 \%)$ e citronelol $(8,2 \%)$. Observou-se mortalidade de $100 \%$ das larvas nas concentrações 7,5 e 10,0 $\mu \mathrm{L} / 20 \mathrm{~mL}$ em 24 horas. Após 48 horas, 93,3\% em 5,0 $\mu \mathrm{L} / 10 \mathrm{~mL}$ de OECN e 70\% em 2,5 $\mu \mathrm{L} / 10 \mathrm{~mL}$, o A. flavus apresentou maior sensibilidade ao OECN a $8,0 \mu \mathrm{L} / 10 \mathrm{~mL}$ do que o A. parasiticus nas concentrações. O $A$. parasiticus foi o mais sensível nas concentrações 1,0 e 2,0 $\mu \mathrm{L} / 10 \mathrm{~mL}$. O OECN possui ação larvicida e atividade antifúngica nas concentrações testadas.
\end{abstract}

Palavras-chave: Óleo essencial; Citronella; Antifúngico; Ação larvicida.

\title{
Resumen
}

El Cymbopogon nardus L. es una planta conocida popularmente como "hierba citronela", originaria de Ceilán y la India, utilizada en Indonesia como té calmante y digestivo. El aceite esencial de la especie Cymbopogon nardus (OECN) se utiliza en la fabricación de cosméticos y perfumes, además de haber demostrado acción antimicrobiana contra Escherichia coli, Salmonella spp., Pseudomonas spp., Streptococcus spp., y además antioxidante, antiinflamatoria. El objetivo de este estudio fue determinar el potencial larvicida y fungicida de OECN extraído de las hojas frescas de $C$. nardus. L al comienzo de la estación seca en Teresina, PI. A partir de la OECN extraída por hidrodestilación, los activos se identificaron mediante cromatografía de gases en masa. La acción larvicida de OECN se probó contra la tercera y cuarta etapa larvaria del Aedes aegypti en concentraciones $(2.5,5.0,7.5$ y $10 \mu \mathrm{L} / 20 \mathrm{ml})$ durante 24 a 48 horas. Actividad antifúngica para Aspergillus flavus y A. parasiticus a concentraciones (1.0, 2.0, 4.0 6.0 y $8.0 \mu \mathrm{L} / 10 \mathrm{~mL})$. La OECN mostró un buen rendimiento $(1,0 \%)$, con 26 activos $(93,2 \%)$ identificados con la mayoría: citronelal $(31,6 \%)$, geraniol $(22,1 \%)$, elemol $(11,8 \%)$ y citronelol $(8,2 \%)$. Se observó una mortalidad del $100 \%$ de las larvas a concentraciones de 7,5 y $10,0 \mu \mathrm{l} / 20 \mathrm{ml}$ en 24 horas. Después de 48 horas 93,3\% en 5,0 $\mu 1 / 10 \mathrm{ml} \mathrm{OECN} \mathrm{y} 70 \%$ en $2,5 \mu \mathrm{l} / 10 \mathrm{ml}$. A. flavus mostró mayor sensibilidad a OECN a $8.0 \mu \mathrm{l} / 10 \mathrm{ml}$ que A. parasiticus a concentraciones. A. parasiticus fue el más sensible a concentraciones de 1.0 y $2.0 \mu \mathrm{L} / 10 \mathrm{~mL}$. OECN tiene una acción larvicida y actividad antifúngica en las concentraciones probadas.

Palabras clave: Aceite esencial; Citronella; Antifúngico; Acción larvicida.

\section{Introduction}

Essential oils (EO) from aromatic plants are secondary metabolites consisting of a mixture of bioactive substances (Pavela, 2016) and an association of different compounds that hinder the formation of resistance by potentially pathogenic organisms. They can also be defined as a set of complex and volatile substances, in general odoriferous and liquid (Sarma et al, 2019). Some plant species considered natural insecticides, such as Eucalyptus globulus, Piper betle, Pogostemon cablin and Ocimum campechianum have larvicidal and ovicidal activity against the Aedes (Stegomyia) aegypti L. (1762) (Kaura et al., 2019; Martianasari et al., 2019; Scalvenzi et al., 2019; Lima Santos et al., 2019).

Cymbopogon nardus L. is a plant popularly known as "citronella", originated from Ceylon and India, used in Indonesia as a soothing and digestive tea. The gender Cymbopogon belongs to the family Poaceae, subfamily Panicoideae, consisting of eighty-five species. The essential oil of the species Cymbopogon nardus (OECN) is used in the manufacture of cosmetics and perfumes, in addition to having shown antimicrobial action against Escherichia coli, Salmonella spp., Pseudomonas spp., Streptococcus spp., and beyond that, antioxidant, anti-inflammatory. The chemical composition of OECN is described in the literature with high content of geraniol and citronellal (Wei et al., 2013; Bayala et al., 2020).

Dengue is caused by an Arbovirus that has four serotypes (DEN-1, DEN-2, DEN-3 and DEN-4) transmitted by the bite of Aedes aegypti infected. This mosquito is also a vector of chikungunya, yellow fever and Zika (Brasil, 2009). To keep the mosquito population under control, it is necessary to maintain urban cleanliness, eliminate still water and use repellents and 
larvicides (Brasil, 2020). Mosquitoes can become resistant to these chemicals, thus, the biological cycle continues and the population increases; hence, there may be more cases of dengue outbreaks (Hamid et al., 2017; Sayono et al., 2016).

Controlling A. aegypti is a major challenge, especially in developing countries. In situations where the resources for vector control are appropriate for carrying out programs, success has not been achieved, several times (Brady et al., 2020; Zara et al., 2016). The factors related to the failure of these programs may be related to the infrastructure of cities, such as: basic sanitation, sewage treatment, inadequate coverage of garbage collection, educational campaigns and discontinuity in water supply (Zara et al., 2016). They can also be related to the population concerning the inadequate storage of water and the elimination of water puddled in backyards, plant pots and other objects. Currently, public health programs aimed at the control of Aedes aegypti employ chemical insecticides such as organophosphates and pyrethroids (temephos, malathion and fenitrothion), but the indiscriminate use of these substances has resulted in the emergence of resistant mosquito populations and environmental damage caused by their intensive use (Ndiath et al., 2019; Fernando et al., 2020).

Fungi are able to cause a series of damage to grains during planting and harvesting, as well as during storage. Several species of filamentous fungi produce mycotoxins, i.e., toxic substances produced mainly by the species. A. parasiticus and Aspergillus flavus through their metabolism, which contaminate food either in the field, in storage or after manufacturing. The Aspergillus flavus is a filamentous fungus which can produce aflatoxins and cyclopiazonic acid, and the co-production of these mycotoxins can favour an additive or synergistic toxic effect on consumers, increasing the toxigenic potential of this fungus (Gonçalez et al., 2013; Prado et al., 2008). Fungal infections are quite frequent, and can be extremely severe and often difficult to manage. Despite the emergence of antimicrobial agents, daily the appearance of strains resistant to the available therapeutic arsenal is observed. It should also be considered that often the available antimicrobials can generate problems for patients, causing treatment abandonment before the expected time for cure (Perlin et al., 2017; Cowen et al., 2015).

Given the problems caused by resistance to chemotherapy, it is crucial to search for alternatives and strategies to combat these agents, and the essential oils can be an interesting outlet for this problem. Such rationale is behind this study aimed at determinig the larvicide and fungicide potential of the species. Cymbopogon nardus $\mathrm{L}$.

\section{Methodology}

\subsection{Material Collection}

Leaves of plant material of the species Cymbopogon nardus (citronella) were collected, at 4 pm, in May 2019, at the Aromatic and Medicinal Plants Department, located at the Agricultural Science Center, Campus Ministro Petrônio Portella, Teresina, Piauí (NUPLAM-UFPI $\left(5^{\circ} 04^{\prime} 35^{\prime \prime} \mathrm{S}, 42^{\circ} 78^{\prime} 38^{\prime \prime} \mathrm{W}\right)$. They were then packed in dark plastic bags and taken to the Laboratory of Organic Geochemistry (LAGO) of the Federal University of Piauí - UFPI, where they remained under refrigeration until the extraction of essential oils.

\subsection{Extraction of Essential Oils}

The EO of the fresh leaves of Cymbopogon nardus were extracted by hydrodistillation for three hours in a Clevenger type device with a temperature of $100^{\circ} \mathrm{C}$ to $105^{\circ} \mathrm{C}$, dried with anhydrous sodium sulfate, that was, then, weighed and stored in a capped flask, coated with aluminum foil and stored in a refrigerator at an average temperature of $4.0^{\circ} \mathrm{C}$, until the moment of gas chromatography analysis coupled to mass spectroscopy (Aguiar et al., 2014). The calculation of EO yield is done using the equation:

\section{Equation 1:}

Yield $(\%)=\underline{\text { Oil mass }(\mathrm{g}) \times 100}$

Leaf mass (g) 


\subsection{Chemical Composition Analysis}

To determine the chemical composition of the $\mathrm{EO}$ from the Cymbopogon nardus species the analysis was performed by Gas Chromatography Coupled to Mass Spectrometry (GC-MS) in MDGC/GCMS-2010 SHIMADZU equipment coupled to a GC-MS-QP5050A mass spectrometer. For the chromatography of the components, a J \& W Scientific column DB-5HT (RTX$5 \mathrm{~mL}$ ) was used $(30 \mathrm{~m} \times 0.25 \mathrm{~mm}$, internal film thickness of $0.25 \mu \mathrm{m})$, and used helium $(\mathrm{He})$ at the flow of $1.0 \mathrm{ml}-1 \mathrm{~min}$ and $1 / 10$ split mode as a carrier gas. The temperature of the injector and detector was kept at $250^{\circ} \mathrm{C}$. Column temperature was programmed from $60^{\circ} \mathrm{C}$ to $240^{\circ} \mathrm{C}$ at a rate of $3.0^{\circ} \mathrm{C}$ min-1 and remaining 10 minutes at $240^{\circ} \mathrm{C}$; a volume of $1.0 \mu 1$ was injected. The ME conditions were quadrupole ion detector type operating by electronic impact with energy of $70 \mathrm{eV}$; 2000 sweep speed; with $250^{\circ} \mathrm{C}$ interface; and fragments detected in the range of 40 to $600 \mathrm{Da}$ e. The identification was made by comparing the standard spectra of the internal data library and the retention times using standards in the same method of analysis (Kovat's Index) (Adams, 2007).

\subsection{Larvicide Action}

To carry out the larvicidal action, was used third and fourth stage larvae of the Aedes aegypti obtained at the Laboratory of Parasitology and Sanitary Entomology (LAPES, UFPI), according to the methodology suggested by the World Health Organization (Who, 2005). EOCN aliquots of 2.5 5.0, 7.5 and $10.0 \mu \mathrm{L}$ of the were diluted in $20.0 \mathrm{ml}$ of $1.0 \%$ (v:v) aqueous dimethylsulfoxide (DMSO) solution directly in polyethylene bottles. The negative control consisted of a $20 \mathrm{ml}$ of a 1.0\% (v:v) DMSO solution. 10 larvae were placed in each polyethylene bottle. The investigation of mortality was observed within $24 \mathrm{~h}$ and $48 \mathrm{~h}$ after the test was performed. The tests were carried out in triplicate.

The mortality efficiency of larvae was determined in percentage through equation 2 (Abbott, 1925).

\section{Equation 2:}

$$
E(\%)=(\underline{N c-N t}) \times 100
$$

$\mathrm{Nc}$

Where:

$\mathrm{E}=$ larval mortality efficiency

$\mathrm{Nc}=$ Number of individuals alive in the control treatment;

$\mathrm{Nt}=$ Number of live individuals treated;

\subsection{Antifungical Activity}

To determine the minimum inhibitory concentration (MIC), the Pandey and Dubey's (1994) modified technique of was used. Concentrations of 2.5; 5.0; 7.5 and $10.0 \mu \mathrm{L}$ of the EOCN were directly homogenized in $10 \mathrm{ml}$ of MEA growth medium (malt extract, glucose, peptone, agar, distilled water) still semi-solid, aseptically poured into Petri dishes (10 x $90 \mathrm{~mm})$. After solidification of the culture medium, a nine-millimeter hole was opened in the center of the plate, using a cutter (punch forceps or $1000 \mu \mathrm{L}$ tip), then aseptically inoculated with $50.0 \mu \mathrm{l}$ of a suspension containing $10^{5}$ Aspergillus flavus and A. parasiticus conidia per ml diluted in phosphate saline buffer, counted with the aid of a Neubauer chamber. Negative controls were also prepared by aseptically placing the MEA culture medium in Petri dishes. The plates were sealed with polyethylene film and inoculated at a temperature of $28.0 \pm 2.0^{\circ} \mathrm{C}$ for seven days. The experiment was run in triplicate. The diameter of the fungus colonies of treatments and the control were measured and the percentage of growth inhibition was calculated according to 
equation 3 (Kumar et al., 2010).

\section{Equation 3:}

\section{Inhibition Mycelial $(\%)=(\underline{\mathbf{d c}-\mathbf{d t}) * 100}$}

dc

Where:

$\mathrm{dc}=$ mean diameter of the colony in the control group;

$\mathrm{dt}=$ mean diameter of the colony in the treatment group.

\subsection{Statistical Analysis}

The data was displayed as a mean \pm standard deviation For the analysis of antifungal activity, the results were expressed as a percentage $(\%)$, using a completely randomized design with a factorial scheme $(2 \times 5 \times 3)$, with two levels of essential oil/fungus (EOCN-Citronella/A. flavus and EOCN-Citronella/A. parasiticus), five levels of concentrations (1.0; 2.0; 4.0; 6.0 and $8.0 \mu \mathrm{L}$ ) and three repetitions (mycelial inhibition). The analysis of variance (ANOVA) was performed using the PROC GLM procedure, from SAS® software, University Edition. The comparison of means in the analysis of parameters was performed using Tukey's mean comparison test, with a significance level of $\mathrm{p}<0.05$.

For the larvicide test, data were expressed as mean \pm standard deviation. For the analysis of larvicidal activity, the results were expressed as a percentage (\%), using a completely randomized design with a factorial scheme $(2 \times 4 \times 3)$, with two levels of mortality/time efficiency (efficiency/24 hours and efficiency/48 hours), four levels of concentrations (2.5; 5.0; 7.5 and $10.0 \mu \mathrm{L})$ and three repetitions.

\section{Results and Discussion}

The OECN yield depends on extrinsic factors: region, climatic conditions and type of cultivation, as well as intrinsic factors related to plant physiology. In the present study in Teresina, PI, the CEON yield was 1.0\%, using the same methodology, despite having been carried out in distant geographic regions but in close climatic conditions. Both the production and the chemical constitution of the essential oils present in the plant depend on a series of edaphoclimatic factors (Pavarini et al., 2012; Wasternack et al., 2016; Wasternack et al., 2017). In this context, Rocha et al. (2012) in Janaúba - MG, obtained yields of 0.2\% and $0.3 \%$, and attributed the low yield to the fact that essential oils are volatile at the high temperature of the region $\left(35^{\circ} \mathrm{C}\right)$. Pereira et al. (2015) in the city of São José dos Pinhais, PR, obtained a monthly income of 2.80\%, higher than that found in other regions of Brazil, which can be justified due to the region's subtropical climate.

With the methodology used, $93.2 \%$ of the chemical compounds present in the essential oil of Cymbopogon nardus was identified. The main constituents are: oxygenated monoterpenes (citronellal, geraniol, citronellol) and hydrocarbon sesquiterpene (elemol) (Figure 1 and Table 1). 
Figure 1: Essential oil chemical composition analysis chromatogram Cymbopogon nardus (Citronella) by Gas Chromatography coupled to Mass Spectrometry.

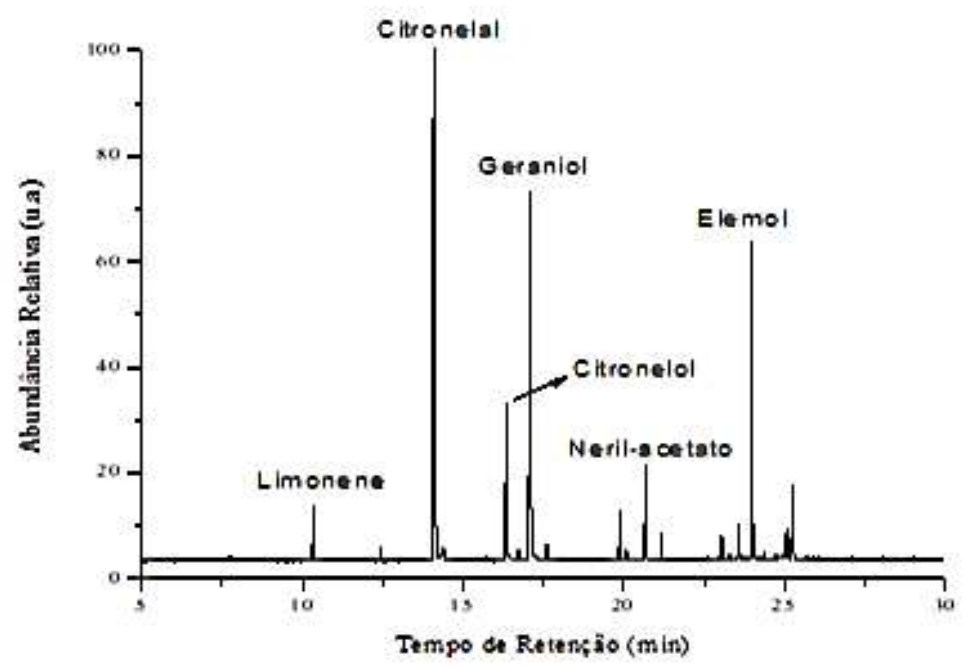

Source: Authors.

Table 1: Identification of essential oil compounds from Cymbopogon nardus (Citronella) leaves by Gas Chromatography coupled to Mass Spectrometry.

\begin{tabular}{|c|c|c|c|c|}
\hline Compound & Similarity & TR & Area (\%) & KI \\
\hline NI & - & 7,760 & 0.12 & - \\
\hline Isovalerone & 78 & 8,026 & 0.07 & 951 \\
\hline Myrcene & 90 & 9,082 & 0.07 & 991 \\
\hline Limonene & 96 & 10,343 & 2.47 & 1031 \\
\hline NI & - & 11,018 & 0.03 & - \\
\hline Alpha-Terpinolene & 89 & 12,083 & 0.05 & 1088 \\
\hline Linalool & 97 & 12453 & 0.57 & 1098 \\
\hline Citronellal & 96 & 14,094 & 31.56 & 1153 \\
\hline NI & - & 14,286 & 0.38 & - \\
\hline NI & - & 14,388 & 0.97 & - \\
\hline Alpha Terpineol & 88 & 15,484 & 0.05 & 1189 \\
\hline Decanal & 95 & 15,724 & 0.09 & 1204 \\
\hline Citronellol & 97 & 16344 & 8.16 & 1228 \\
\hline Neral & 95 & 16732 & 0.54 & 1240 \\
\hline Geraniol & 96 & 17085 & 22.06 & 1255 \\
\hline Geranial & 96 & 17598 & 0.77 & 1270 \\
\hline Citronellyl Acetate & 95 & 19868 & 2.51 & 1354 \\
\hline Eugenol & 96 & 20067 & 0.53 & 1356 \\
\hline Neryl Acetate & 96 & 20672 & 4.77 & 1365 \\
\hline NI & - & 20963 & 0.06 & - \\
\hline Beta-Elemene & 95 & 21,159 & 1.3 & 1375 \\
\hline NI & - & 22,587 & 0.11 & - \\
\hline NI & - & 22,865 & 0.03 & - \\
\hline NI & - & 22,915 & 0.06 & - \\
\hline Germacrene-d & 98 & 23,045 & 0.87 & 1480 \\
\hline Alpha-Muurolene & 95 & 23,286 & 0.26 & 1499 \\
\hline
\end{tabular}




\begin{tabular}{|c|c|c|c|c|}
\hline Damma-Cadinene & 92 & 23519 & 0.14 & 1513 \\
\hline Delta-Cadinene & 94 & 23573 & 1.43 & 1524 \\
\hline NI & - & 23,665 & 0.1 & - \\
\hline NI & - & 23,720 & 0.05 & - \\
\hline NI & - & 23,782 & 0.06 & - \\
\hline NI & - & 23,843 & 0.04 & - \\
\hline Elemol & 92 & 23,976 & 11.84 & 1547 \\
\hline NI & - & 24145 & 0.08 & - \\
\hline Germacrene d-4-ol & 86 & 24,370 & 0.24 & 1574 \\
\hline NI & - & 24672 & 0.07 & - \\
\hline NI & - & 24,722 & 0.18 & - \\
\hline NI & - & 24,821 & 0.12 & - \\
\hline NI & - & 24,930 & 0.34 & - \\
\hline 10-Epi-Gamma-Eudesmol & 90 & 24,999 & 0.94 & 1602 \\
\hline Alpha-Cadinol & 88 & 25,105 & 1.79 & 1653 \\
\hline NI & - & 25227 & 3.48 & - \\
\hline (Z,E)-Farnesal & 76 & 25,635 & 0.03 & 1688 \\
\hline Z,Z-Farnesol & 95 & 25,674 & 0.12 & 1713 \\
\hline NI & - & 25868 & 0.06 & - \\
\hline NI & - & 26,055 & 0.08 & - \\
\hline NI & - & 27,066 & 0.07 & - \\
\hline NI & - & 28,016 & 0.08 & - \\
\hline NI & - & 29,015 & 0.1 & - \\
\hline NI & - & 30,206 & 0.1 & - \\
\hline Total & & & $100 \%$ & \\
\hline
\end{tabular}

KI: Kovats index; RT: Retention time; NI: Not identified. Source: Authors.

Shortly after 24 hours, it was observed that at the concentration of $2.5 \mu \mathrm{L} 63.33 \%$ of the larvae died, with $5 \mu \mathrm{L}, 83.33 \%$, and with 7.5 and $10 \mu \mathrm{L} 100 \%$ of the Aedes aegypti mosquito larvae had been eliminated. This shows the potential of the larvicidal action of EOCN against the larvae. Mortality rates and standard deviation in each concentration were organized and can be seen in table 2 .

Table 2: Larvicidal activity of the Essential Oil of Cymbopogon nardus (Citronella), under larvae of Aedes aegypti.

\begin{tabular}{lcc}
\hline Concentrations $(\boldsymbol{\mu L})$ & $\begin{array}{c}\text { Larvicide activity }(\%) \\
\text { 24-hour mortality efficiency } \\
(\dot{\mathrm{X}} \pm \mathrm{SD})\end{array}$ & $\begin{array}{c}\text { 48-hour mortality efficiency } \\
(\dot{\mathrm{X}} \pm \mathrm{SD})\end{array}$ \\
\hline 2.5 & $63.3^{\mathrm{ba}} \pm 24.94$ & $70.0^{\mathrm{aA}} \pm 29.43$ \\
5.0 & $83.3^{\mathrm{abA}} \pm 4.71$ & $93.3^{\mathrm{aA}} \pm 12.77$ \\
7.5 & $100.0^{\mathrm{aA}} \pm 0.00$ & $100.0^{\mathrm{aA}} \pm 0.00$ \\
10.0 & $100.0^{\mathrm{aA}} \pm 0.00$ & $100.0^{\mathrm{aA}} \pm 0.00$ \\
\hline
\end{tabular}

$\dot{X}$ : mean, SD: standard deviation. Means followed by different lowercase letters in the same column $\left({ }^{a}, b, c p<0.05\right)$ and uppercase letters in the same row $\left({ }^{A}, \mathrm{~B} p<0.05\right)$ differ significantly by Tukey's test at $5 \%$ probability $(\mathrm{p}<0.05)$. Source: Authors, 2021.

According to the results obtained in Table 3, against the strains of Aspergillus flavus and A. parasiticus, it is possible to observe the antifungal action of citronella essential oil, varying depending on the concentration used. An increase in mycelial inhibition is observed as the concentration of OECN increases. 
Table 3: Antifungal Activity of the Essential Oil of Cymbopogon nardus (Citronella), under the growth inhibition of Aspergillus flavus and Aspergillus parasiticus.

\begin{tabular}{lll}
\hline Concentrations $(\boldsymbol{\mu L})$ & $\begin{array}{l}\text { Inhibition of Mycelial Growth }(\%) \\
\text { A. flavus } \\
(\dot{\mathrm{X}} \pm \mathrm{SD})\end{array}$ & $\begin{array}{l}\text { A. parasiticus } \\
(\dot{\mathrm{X}} \pm \mathrm{SD})\end{array}$ \\
\hline 1 & $1.5^{\mathrm{cA}} \pm 1.50$ & $9.6^{\mathrm{bA}} \pm 1.50$ \\
2 & $8.1^{\mathrm{bcA}} \pm 4.86$ & $10.6^{\mathrm{aA}} \pm 6.99$ \\
4 & $15.7^{\mathrm{bcA}} \pm 8.32$ & $14.6^{\mathrm{abA}} \pm 8.15$ \\
6 & $27.8^{\mathrm{abA}} \pm 12.70$ & $22.4^{\mathrm{abA}} \pm 4.80$ \\
8 & $45.0^{\mathrm{yy}} \pm 6.82$ & $32.9^{\mathrm{yy}} \pm 15.11$ \\
\hline
\end{tabular}

$\dot{X}$ : mean, SD: standard deviation. Means followed by different lowercase letters in the same column $\left({ }^{\mathrm{a}, \mathrm{b}, \mathrm{c}} \mathrm{p}<0.05\right)$ and uppercase letters in the same row $\left({ }^{\mathrm{A}, \mathrm{B}} \mathrm{p}<0.05\right)$ differ significantly by Tukey's test at $5 \%$ probability $(\mathrm{p}<0.05)$. Source: Authors (2021).

Citronellal is the major compound that confers the characteristic odor of the EOCN (Koba et al., 2009), being the majority in works performed by Wei et al. (2013), Nakahara et al. (2013) in Kelantan (Malaysia) and Aguiar et al. (2014) in Gurupi and Dueré (Tocantins). The components and proportions found in the EOCN in this study (Table 1) do not correspond to those obtained by other respondents in the literature. Bayala et al. (2020) while observing the chemical composition and biological activities of Cymbopogon nardus essential oil in a country of the African continent found citronellal (33.06\%19.56min), geraniol (28.40\%-22,57min), nerol (10.94\%-21.80min), elemol (5.25\%-30.52min) and delta-elemene (4.09\%$26.43 \mathrm{~min})$ as respective majoritarian and retention times, De Toledo et al. (2016) in their study found that the OECN has citronellal (27.87\%-12.54min), geraniol (22.77\%-16.73min), geranial (14.54\%-17.38min), citronellol (11.85\%-15.60min), and nerol (11.21\%-16.12min) as main constituents. Both authors consider that these variation of chemical compounds and retention times found in the EOCN may have occurred due to climatic differences, soil type, form of cultivation and geographic location. where the plant was collected.

Dengue is a serious public health concern in the world, being one of the most important arboviruses affecting humans. In tropical countries, including Brazil, this disease occurs where environmental conditions favour the development and proliferation of its vector Aedes aegypti (Viana et al., 2013; Rodrigues et al., 2013).

The indiscriminate use of insecticides to control dengue has promoted the emergence of resistant populations of $A$. aegypti, in addition to having had undesirable effects such long time permanence in the environment (Ryan et al., 2019; Satoto et al., 2019; Demok et al., 2019). An alternative would be the use of natural insecticides to control this vector. In this sense, Veloso et al. (2015), describe the larvicidal activity of the essential oil of the species Cymbopogon nardus (Citronella) collected in a northern Brazilian state in front of the Aedes aegypti, with aliquots of 5, 7.5 and $10 \mu \mathrm{L}$ with greater larvicidal action, demonstrating a percentage of $100 \%$ of dead larvae of the exposed vector in the first 6 hours, showing the potential of the essential oil to counter the development and proliferation of this vector.

This shows the potential of the larvicidal action of EOCN against the larvae. In a study performed by Govindarajan et al. (2016) it was demonstrated that eugenol, $\alpha$-pinene and $\beta$-caryophyllene tested alone in larvae of Anopheles subpictus, Aedes albopictus and Culex tritaenior hynchus were more effective than the essential oil of the plant (Plectranthus barbatus) used in the tests. In the study by Silva et al. (2018) involving compounds isolated from the essential oil of Aristolochia trilobata, the monoterpenes p-cimene and limonene stood out, revealing a lot of toxicity for the larvae of Aedes aegypti although $\alpha$ - and $\beta$ pinene monoterpenes also have larvicidal activity. In a work by Andrade-Ochoa et al. (2018) when evaluating the larvicidal activity of terpenes and terpenoids obtained from a distributor, against the Box. quinquefasciatus it was possible to observe that citronellal revealed larvicidal action against third and fourth stage larvae of the insect vector, in relation to the Aedes aegypti studies have shown that citronellal is isolated from Myroxylon balsamum as industrially obtained it also has larvicidal action in 
all larval stages (Simas et al., 2004; Waliwitia et al., 2009). In studies performed by Liu et al. (2013) and Tabari et al. (2017), when analysing the toxicity of compounds isolated from the essential oils of Pelargonium roseum and All asian demonstrated that geraniol has strong larvicidal activity against Pipes box and A. albopictus. According to Dias et al. (2014) and Cheng et al. (2009) elemol is classified as a non-active sesquiterpene against aedes aegypti larvae since its LC50\% value is $>100 \mathrm{mg} / \mathrm{L}$. According to Tabari et al. (2017) citronellol from the essential oil of Pelargonium roseum revealed larvicidal activity against third-stage larvae of Anopheles Gambia and Culex pipes.

Due to the high mortality rates presented and the presence of compounds that are proven to be toxic observed in this study, it is possible to associate the results found with the hypotheses already proposed by Pavela et al. (2015) and Tak et al. (2017) that there was synergism between the components of the essential oil of Cymbopogon nardus.

The antifungal potential of EO is associated with its chemical components. The antimicrobial action of essential oils has been directly linked to the presence of compounds such as terpinenol, citronellal, cineol, limonene and cymene (Souza et al., 2005; Mondello et al., 2006). According to Gao et al. (2011), when studying antibacterial activity of citral isolated from Cymbopogon flexuosus observed that the substance was able to reduce the biofilm biomass and cell viability in the biofilm of Staphylococcus aureus and Candida spp. in vitro. According to Leite et al. (2014), citral has antifungal activity against Candida spp. in vitro, and the minimum inhibitory concentration values $(64 \mu \mathrm{g} / \mathrm{mL})$ and minimum fungicidal concentration $(256 \mu \mathrm{g} / \mathrm{ml})$ were sufficient to inhibit $99.9 \%$ of the inoculum during 4 hours of exposure.

A study by $\mathrm{Wu}$ et al. (2016) showed that citronellal caused a reduction in the development of spores of P. digitatum which varied with dose, along with damage to the plasma membrane. In another study by Aguiar et al. (2014) citronellal was the main component in the two plants studied (C. citriodora and C. nardus) and revealed growth inhibition for fungal species Pyricularia (Magnaporthe) grisea, and Colletotrichum musae.

Regarding geraniol, the Tang study et al. (2018) revealed antifungal activity against A. flavus and A. ochraceus in vitro and in situ, and among the mechanisms involved, the increase in cell membrane permeability and production of reactive oxygen species stand out. Leite et al. (2015) revealed in their study that geraniol was able to inhibit growth in strains of C. albicans, in vitro. With regard to citronellol, a work by Pereira et al. (2015) showed antifungal activity against strains of T. rubrum and the mechanism of action is related to ergosterol biosynthesis.

\section{Conclusion}

The essential oil of Cymbopogon nardus (Citronella) presented antifungal activity and potent larvicidal activity, against the growth of Aspergillus flavus, Aspergillus parasiticus and larvae of Aedes aegypti, besides being quite rich in secondary metabolites. It was also observed that the action of the essential oil was dependent on the amount used. These results strengthen the continuity of further studies with the species in biomedical applications, and reinforce the potential of essential oil as an instrument for obtaining secondary metabolites and developing new drugs/medications.

\section{References}

Abbott, W. (1987). A method of computing the effectiveness of an insecticide. Journal of the American Mosquito Control Association, 3(2), $302-303$.

Adams, R. P. (2007). Identification of essential oil components by gas chromatography/mass spectrometry (Vol. 456). Allured publishing corporation Carol Stream, IL.

Aguiar, R. W. de S., Ootani, M. A., Ascencio, S. D., Ferreira, T. P., Santos, M. M. dos, \& Santos, G. R. dos. (2014). Fumigant antifungal activity of Corymbia citriodora and Cymbopogon nardus essential oils and citronellal against three fungal species. The Scientific World Journal, 2014.

Andrade-Ochoa, S., Correa-Basurto, J., Rodríguez-Valdez, L. M., Sánchez-Torres, L. E., Nogueda-Torres, B., \& Nevárez-Moorillón, G. V. (2018). In vitro and in silico studies of terpenes, terpenoids and related compounds with larvicidal and pupaecidal activity against Culex quinquefasciatus Say (Diptera: Culicidae). Chemistry Central Journal, 12(1), 1-21. 
Ayoola, G. A., Lawore, F. M., Adelowotan, T., Aibinu, I. E., Adenipekun, E., Coker, H. A. B., \& Odugbemi, T. O. (2008). Chemical analysis and antimicrobial activity of the essential oil of Syzigium aromaticum (clove). African Journal of Microbiology Research, 2(7), $162-166$.

Bayala, B., Coulibaly, A. Y., Djigma, F. W., Nagalo, B. M., Baron, S., Figueredo, G., Lobaccaro, J.-M. A., \& Simpore, J. (2020). Chemical composition, antioxidant, anti-inflammatory and antiproliferative activities of the essential oil of Cymbopogon nardus, a plant used in traditional medicine. Biomolecular Concepts, 11(1), 86-96.

Brady, O. J., \& Hay, S. I. (2020). The global expansion of dengue: How Aedes aegypti mosquitoes enabled the first pandemic arbovirus. Annual Review of Entomology, 65, 191-208.

Brito, R., Lopes, H. M., Paulo, H. H., Lima, A. C., Fernandes, M. C. A., \& Brandao, A. A. (2018). Utilização de Óleos Essenciais de Capim-limão (Cymbompogon citratus), Citronela (Cymbopogon nardus) e Óleo de Nim (Azarirachta indica) no Controle de Insetos e Microorganismos. Cadernos de Agroecologia, 13(1).

Burt, S. A., \& Reinders, R. D. (2003). Antibacterial activity of selected plant essential oils against Escherichia coli O157: H7. Letters in Applied Microbiology, $36(3), 162-167$

Brasil, Ministério da Saúde, Secretaria de Vigilância em Saúde, Departamento de Vigilância Epidemiológica. (2009). Diretrizes nacionais para prevenção e controle de epidemias de dengue.

Cheng, S. S., Lin, C. Y., Chung, M. J., Liu, Y. H., Huang, C. G., \& Chang, S. T. (2013). Larvicidal activities of wood and leaf essential oils and ethanolic extracts from Cunninghamia konishii Hayata against the dengue mosquitoes. Industrial Crops and Products, 47, 310-315.

Cheng, S.-S., Chua, M.-T., Chang, E.-H., Huang, C.-G., Chen, W.-J., \& Chang, S.-T. (2009). Variations in insecticidal activity and chemical compositions of leaf essential oils from Cryptomeria japonica at different ages. Bioresource Technology, 100(1), 465-470.

Cowen, L. E., Sanglard, D., Howard, S. J., Rogers, P. D., \& Perlin, D. S. (2015). Mechanisms of antifungal drug resistance. Cold Spring Harbor perspectives in medicine, 5(7), a019752.

Cunha, B. G., Duque, C., Caiaffa, K. S., Massunari, L., Catanoze, I. A., Dos Santos, D. M., de Oliveira, S. H. P., \& Guiotti, A. M. (2020). Cytotoxicity and antimicrobial effects of citronella oil (Cymbopogon nardus) and commercial mouthwashes on S. aureus and C. albicans biofilms in prosthetic materials. Archives of Oral Biology, 109, 104577.

De Toledo, L. G., Ramos, M. A. D. S., Spósito, L., Castilho, E. M., Pavan, F. R., Lopes, É. D. O., Zocolo, G. J., Silva, F. A. N., Soares, T. H., \& Dos Santos, A. G. (2016). Essential oil of Cymbopogon nardus (L.) Rendle: A strategy to combat fungal infections caused by Candida species. International Journal of Molecular Sciences, 17(8), 1252.

Demok, S., Endersby-Harshman, N., Vinit, R., Timinao, L., Robinson, L. J., Susapu, M., Makita, L., Laman, M., Hoffmann, A., \& Karl, S. (2019). Insecticide resistance status of Aedes aegypti and Aedes albopictus mosquitoes in Papua New Guinea. Parasites \& Vectors, 12(1), 1-8.

Dias, C. N. (2013). Avaliação da atividade larvicida em Aedes aegypti L. (Diptera: Culicidae) de óleos essenciais de espécies vegetais: Um estudo de revisão e bioprospecção.

Dias, C. N., \& Moraes, D. F. C. (2014). Essential oils and their compounds as Aedes aegypti L. (Diptera: Culicidae) larvicides. Parasitology Research, 113(2), $565-592$.

Fernando, H. S. D., Saavedra-Rodriguez, K., Perera, R., Black, W. C., \& De Silva, B. N. K. (2020). Resistance to commonly used insecticides and underlying mechanisms of resistance in Aedes aegypti (L.) from Sri Lanka. Parasites \& Vectors, 13(1), 1-14.

Gao, S., Liu, G., Li, J., Chen, J., Li, L., Li, Z., Zhang, X., Zhang, S., Thorne, R. F., \& Zhang, S. (2020). Antimicrobial activity of lemongrass essential oil (Cymbopogon flexuosus) and its active component citral against dual-species biofilms of Staphylococcus aureus and Candida species. Frontiers in Cellular and Infection Microbiology, 10.

Gonçalez, E., Silva, J. L. da, Reis, T. A., Nakai, V. K., Felicio, J. D., \& Corrêa, B. (2013). Produção de aflatoxinas e ácido ciclopiazônico por cepas de Aspergillus flavus isoladas de amendoim. Arquivos Do Instituto Biológico, 80, 312-317.

Govindarajan, M., Rajeswary, M., Hoti, S. L., Bhattacharyya, A., \& Benelli, G. (2016). Eugenol, $\alpha$-pinene and $\beta$-caryophyllene from Plectranthus barbatus essential oil as eco-friendly larvicides against malaria, dengue and Japanese encephalitis mosquito vectors. Parasitology Research, 115(2), 807-815.

Hamid, P. H., Prastowo, J., Ghiffari, A., Taubert, A., \& Hermosilla, C. (2017). Aedes aegypti resistance development to commonly used insecticides in Jakarta, Indonesia. PLoS One, 12(12), e0189680.

Hamid, P. H., Prastowo, J., Widyasari, A., Taubert, A., \& Hermosilla, C. (2017). Knockdown resistance (kdr) of the voltage-gated sodium channel gene of Aedes aegypti population in Denpasar, Bali, Indonesia. Parasites \& Vectors, 10(1), 1-9.

Hung, N. H., Satyal, P., Hieu, H. V., Chuong, N. T. H., Dai, D. N., Huong, L. T., Tai, T. A., \& Setzer, W. N. (2019). Mosquito larvicidal activity of the essential oils of Erechtites species growing wild in Vietnam. Insects, 10(2), 47.

Kandimalla, R., Kalita, S., Choudhury, B., Dash, S., Kalita, K., \& Kotoky, J. (2016). Chemical composition and anti-candidiasis mediated wound healing property of Cymbopogon nardus essential oil on chronic diabetic wounds. Frontiers in Pharmacology, 7, 198.

Kaura, T., Mewara, A., Zaman, K., Sharma, A., Agrawal, S. K., Thakur, V., Garg, A., \& Sehgal, R. (2019). Utilizing larvicidal and pupicidal efficacy of Eucalyptus and neem oil against Aedes mosquito: An approach for mosquito control. Tropical Parasitology, 9(1), 12.

Koba, K., Sanda, K., Guyon, C., Raynaud, C., Chaumont, J. P., \& Nicod, L. (2009). In vitro cytotoxic activity of Cymbopogon citratus L. and Cymbopogon nardus L. essential oils from Togo. ||| Bangladesh Journal of Pharmacology|||, 4(1), 29-34. 
Kpoviessi, S., Bero, J., Agbani, P., Gbaguidi, F., Kpadonou-Kpoviessi, B., Sinsin, B., Accrombessi, G., Frédérich, M., Moudachirou, M., \& Quetin-Leclercq, J. (2014). Chemical composition, cytotoxicity and in vitro antitrypanosomal and antiplasmodial activity of the essential oils of four Cymbopogon species from Benin. Journal of Ethnopharmacology, 151(1), 652-659.

Kumar, A., Shukla, R., Singh, P., \& Dubey, N. K. (2010). Chemical composition, antifungal and antiaflatoxigenic activities of Ocimum sanctum L. essential oil and its safety assessment as plant based antimicrobial. Food and Chemical Toxicology, 48(2), 539-543.

Leite, M. C. A., Bezerra, A. P. de B., Sousa, J. P., Guerra, F. Q. S., \& Lima, E. de O. (2014). Evaluation of antifungal activity and mechanism of action of citral against Candida albicans. Evidence-Based Complementary and Alternative Medicine, 2014.

Leite, M. C. A., de Brito Bezerra, A. P., de Sousa, J. P., \& de Oliveira Lima, E. (2015). Investigating the antifungal activity and mechanism (s) of geraniol against Candida albicans strains. Medical Mycology, 53(3), 275-284.

Lima Santos, L., Barreto Brandão, L., Lopes Martins, R., de Menezes Rabelo, E., Lobato Rodrigues, A. B., da Conceição Vieira Araújo, C. M., Fernandes Sobral, T., Ribeiro Galardo, A. K., de Ameida, M. da S., \& Susan, S. (2019). Evaluation of the larvicidal potential of the essential oil pogostemon cablin (Blanco) Benth in the control of Aedes aegypti. Pharmaceuticals, 12(2), 53.

Liu, X. C., Dong, H. W., Zhou, L., Du, S. S., \& Liu, Z. L. (2013). Essential oil composition and larvicidal activity of Toddalia asiatica roots against the mosquito Aedes albopictus (Diptera: Culicidae). Parasitology Research, 112(3), 1197-1203.

Marco, C. A., Innecco, R., Mattos, S. H., Borges, N. S., \& Nagao, E. O. (2007). Características do óleo essencial de capim-citronela em função de espaçamento, altura e época de corte. Horticultura Brasileira, 25, 429-432.

Martianasari, R., \& Hamid, P. H. (2019). Larvicidal, adulticidal, and oviposition-deterrent activity of Piper betle L. essential oil to Aedes aegypti. Veterinary World, 12(3), 367.

Mondello, F., De Bernardis, F., Girolamo, A., Cassone, A., \& Salvatore, G. (2006). In vivo activity of terpinen-4-ol, the main bioactive component of Melaleuca alternifolia Cheel (tea tree) oil against azole-susceptible and-resistant human pathogenic Candida species. BMC Infectious Diseases, 6(1), 1-8.

Nakahara, K., Alzoreky, N. S., Yoshihashi, T., Nguyen, H. T., \& Trakoontivakorn, G. (2013). Chemical composition and antifungal activity of essential oil from Cymbopogon nardus (citronella grass). Japan Agricultural Research Quarterly: JARQ, 37(4), 249-252.

Ndiath, M. O. (2019). Insecticides and insecticide resistance. In Malaria Control and Elimination (pp. 287-304). Humana, New York, NY.

Nzeako, B. C., Al-Kharousi, Z. S., \& Al-Mahrooqui, Z. (2006). Antimicrobial activities of clove and thyme extracts. Sultan Qaboos University Medical Journal, $6(1), 33$.

Pavarini, D. P., Pavarini, S. P., Niehues, M., \& Lopes, N. P. (2012). Exogenous influences on plant secondary metabolite levels. Animal Feed Science and Technology, 176(1-4), 5-16.

Pavela, R. (2015). Acute toxicity and synergistic and antagonistic effects of the aromatic compounds of some essential oils against Culex quinquefasciatus Say larvae. Parasitology Research, 114(10), 3835-3853.

Pavela, R. (2016). History, presence and perspective of using plant extracts as commercial botanical insecticides and farm products for protection against insectsa review. Plant Protection Science, 52(4), 229-241.

Pereira, F. de O., Mendes, J. M., Lima, I. O., Mota, K. S. de L., Oliveira, W. A. de, \& Lima, E. de O. (2015). Antifungal activity of geraniol and citronellol, two monoterpenes alcohols, against Trichophyton rubrum involves inhibition of ergosterol biosynthesis. Pharmaceutical Biology, 53(2), $228-234$.

Perlin, D. S., Rautemaa-Richardson, R., \& Alastruey-Izquierdo, A. (2017). The global problem of antifungal resistance: prevalence, mechanisms, and management. The Lancet Infectious Diseases, 17(12), e383-e392.

Pinto, E., Vale-Silva, L., Cavaleiro, C., \& Salgueiro, L. (2009). Antifungal activity of the clove essential oil from Syzygium aromaticum on Candida, Aspergillus and Dermatophyte species. Journal of Medical Microbiology, 58(11), 1454-1462.

Prado, G., de Assis Souza, R., Morais, V. A. D., Madeira, J. E. G. C., de Oliveira, M. S., de Andrade, M. C., de Godoy, I. J., Rosa, C. A., Junior, A. C., \& Peluzio, J. M. (2008). Influência de Saccharomycopsis schoenii e Saccharomycopsis crataegensis na produção de aflatoxinas B1 e G1 por Aspergillus parasiticus em amendoim (Arachis hypogaea L.). Revista Do Instituto Adolfo Lutz, 67(3), 177-182.

Rocha, H. C. R., Alvarenga, C. D., Giustolin, T. A., Brant, R. S., Souza, M. D. C., Sarmento, H. G. S., \& Barbosa, M. G. (2012). Crescimento, produção de fitomassa e teor de óleo essencial de folhas de capim citronela (Cymbopogon nardus (L.) Rendle) em cultivo consorciado com algodoeiro colorido no semiárido mineiro. Revista Brasileira de Plantas Medicinais, 14, 183-187.

Rodrigues, N. C. P., Lino, V. T. S., Daumas, R. P., Andrade, M. K. de N., O’Dwyer, G., Monteiro, D. L. M., Gerardi, A., Fernandes, G. H. B. V., Ramos, J. A. S., \& Ferreira, C. E. G. (2016). Temporal and spatial evolution of dengue incidence in Brazil, 2001-2012. PLoS One, 11(11), e0165945.

Ryan, S. J., Mundis, S. J., Aguirre, A., Lippi, C. A., Beltrán, E., Heras, F., Sanchez, V., Borbor-Cordova, M. J., Sippy, R., \& Stewart-Ibarra, A. M. (2019). Seasonal and geographic variation in insecticide resistance in Aedes aegypti in southern Ecuador. PLoS Neglected Tropical Diseases, 13 (6), e0007448.

Sarma, R., Adhikari, K., Mahanta, S., \& Khanikor, B. (2019). Combinations of plant essential oil based terpene compounds as larvicidal and adulticidal agent against Aedes aegypti (Diptera: Culicidae). Scientific Reports, 9(1), 1-12.

Satoto, T. B. T., Satrisno, H., Lazuardi, L., \& Diptyanusa, A. (2019). Insecticide resistance in Aedes aegypti: An impact from human urbanization? Plos One, 14(6), e0218079. 
Sayono, S., Hidayati, A. P. N., Fahri, S., Sumanto, D., Dharmana, E., Hadisaputro, S., Asih, P. B. S., \& Syafruddin, D. (2016). Distribution of voltage-gated sodium channel (Nav) alleles among the Aedes aegypti populations in central Java Province and its association with resistance to pyrethroid insecticides. $P L o S$ One, 11(3), e0150577.

Scalvenzi, L., Radice, M., Toma, L., Severini, F., Boccolini, D., Bella, A., Guerrini, A., Tacchini, M., Sacchetti, G., \& Chiurato, M. (2019). Larvicidal activity of Ocimum campechianum, Ocotea quixos and Piper aduncum essential oils against Aedes aegypti. Parasite, 26.

Silva, F. F. da. (2017). Potencial toxicológico e o impacto do piriproxifeno nos parâmetros zootécnicos de tilápia do nilo (Oreochromis niloticus Linnaeus, 1758).

Silva, I. M., Martins, G. F., Melo, C. R., Santana, A. S., Faro, R. R., Blank, A. F., Alves, P. B., Picanço, M. C., Cristaldo, P. F., \& Araújo, A. P. A. (2018). Alternative control of Aedes aegypti resistant to pyrethroids: Lethal and sublethal effects of monoterpene bioinsecticides. Pest Management Science, 74(4), 1001-1012.

Simas, N. K., Lima, E. da C., Conceição, S. da R., Kuster, R. M., Oliveira Filho, A. M. de, \& Lage, C. L. S. (2004). Natural products for dengue transmission control: Larvicidal activity of Myroxylon balsamum (red oil) and of terpenoids and phenylpropanoids. Quimica Nova, 27(1), 46-49.

Souza, E. L. de, Lima, E. de O., Freire, K. R. de L., \& Sousa, C. P. de. (2005). Inhibitory action of some essential oils and phytochemicals on the growth of various moulds isolated from foods. Brazilian Archives of Biology and Technology, 48, 245-250.

Tabari, M. A., Youssefi, M. R., Esfandiari, A., \& Benelli, G. (2017). Toxicity of $\beta$-citronellol, geraniol and linalool from Pelargonium roseum essential oil against the West Nile and filariasis vector Culex pipiens (Diptera: Culicidae). Research in Veterinary Science, 114, 36-40.

Tak, J.-H., \& Isman, M. B. (2017). Penetration-enhancement underlies synergy of plant essential oil terpenoids as insecticides in the cabbage looper, Trichoplusia ni. Scientific Reports, 7(1), 1-11.

Tang, X., Shao, Y.-L., Tang, Y.-J., \& Zhou, W.-W. (2018). Antifungal activity of essential oil compounds (geraniol and citral) and inhibitory mechanisms on grain pathogens (Aspergillus flavus and Aspergillus ochraceus). Molecules, 23(9), 2108.

Teixeira, B., Marques, A., Ramos, C., Neng, N. R., Nogueira, J. M., Saraiva, J. A., \& Nunes, M. L. (2013). Chemical composition and antibacterial and antioxidant properties of commercial essential oils. Industrial Crops and Products, 43, 587-595.

Veloso, R. A., de Castro, H. G., Cardoso, D. P., Chagas, L. F. B., \& Júnior, A. F. C. (2015). Óleos essenciais de manjericão e capim citronela no controle de larvas de Aedes aegypti. Revista Verde de Agroecologia e Desenvolvimento Sustentável, 10(2), 16.

Viana, D. V., \& Ignotti, E. (2013). The ocurrence of dengue and weather changes in Brazil: A systematic review. Revista Brasileira de Epidemiologia, 16, 240256.

Vieira Santos, V. S., Caixeta, E. S., Campos Júnior, E. O. de, \& Pereira, B. B. (2017). Ecotoxicological effects of larvicide used in the control of Aedes aegypti on nontarget organisms: Redefining the use of pyriproxyfen. Journal of Toxicology and Environmental Health, Part A, 80(3), 155-160.

Waliwitiya, R., Kennedy, C. J., \& Lowenberger, C. A. (2009). Larvicidal and oviposition-altering activity of monoterpenoids, trans-anithole and rosemary oil to the yellow fever mosquito Aedes aegypti (Diptera: Culicidae). Pest Management Science: Formerly Pesticide Science, 65(3), $241-248$.

Wasternack, C., \& Song, S. (2017). Jasmonates: Biosynthesis, metabolism, and signaling by proteins activating and repressing transcription. Journal of Experimental Botany, 68(6), 1303-1321.

Wasternack, C., \& Strnad, M. (2019). Jasmonates are signals in the biosynthesis of secondary metabolites_-Pathways, transcription factors and applied aspects_A brief review. New Biotechnology, 48, 1-11.

Wei, L. S., \& Wee, W. (2013). Chemical composition and antimicrobial activity of Cymbopogon nardus citronella essential oil against systemic bacteria of aquatic animals. Iranian Journal of Microbiology, 5(2), 147.

World Health Organization (2005). Guidelines for laboratory and field testing of mosquito larvicides (No. WHO/CDS/WHOPES/GCDPP/2005.13). World Health Organization.

Wu, Y., OuYang, Q., \& Tao, N. (2016). Plasma membrane damage contributes to antifungal activity of citronellal against Penicillium digitatum. Journal of Food Science and Technology, 53(10), 3853-3858.

Yingngam, B., Supaka, N., \& Rungseevijitprapa, W. (2015). Optimization of process parameters for phenolics extraction of Cratoxylum formosum ssp. Formosum leaves by response surface methodology. Journal of Food Science and Technology, 52(1), 129-140.

Zara, A. L. de S. A., Santos, S. M. dos, Fernandes-Oliveira, E. S., Carvalho, R. G., \& Coelho, G. E. (2016). Estratégias de controle do Aedes aegypti: Uma revisão. Epidemiologia e Serviços de Saúde, 25, 391-404. 